\title{
Precambrian Geologic Evolution of THE Teton Range, Western WyOMING
}

\author{
KEVIN R. CHAMBERLAIN $\downarrow$ B.RON FROST $\downarrow$ CAROL D. FROST \\ DEPARTMENT OF GEOLOGY AND GEOPHYSICS \\ UNIVERSITY OF WYOMING $\downarrow$ LARAMIE
}

\section{$\downarrow \quad$ PROJECT SUMMARY}

The crystalline rocks that form the core of the Teton Range are part of the Wyoming Province, which is one of the oldest portions of North America. Study of the basement of the Tetons, coupled with the results of ongoing research in similar-aged rocks exposed elsewhere in Wyoming, will provide information on how the crust evolved in the early Earth in general and in the Wyoming province in particular. In 1999 the project involved two weeks of fieldwork in Grand Teton National Park and regions to the east, including the Gros Ventre Range, deep canyons of the Buffalo Fork River near Togwotee Pass, and outcrops of basement near Dubois, Wyoming. The main goals of the fieldwork were to complete the sampling of key units in Grand Teton National Park, and to determine whether or not the next nearest outcrops of basement (Gros Ventre, Togwotee Pass and Dubois regions) share the early geologic history preserved in the rocks of Teton National Park. This field work involved four faculty members from UW and a graduate student, who is doing the study as part of her MS thesis. Several months of laboratory analysis at UW have characterized the rocks through thin section, stained slabs, and whole rock geochemical and $\mathrm{Nd}, \mathrm{Sr}$, and $\mathrm{Pb}$ isotopic methods and produced preliminary $\mathrm{U}-\mathrm{Pb}$ dates. The principal results from this year's efforts are that the Teton basement rocks consist of large proportions of juvenile crust, the majority of the rocks formed over a relatively narrow time span from $\sim 2.74$ to $2.68 \mathrm{Ga}$, they were deformed at about 2.67 $\mathrm{Ga}$, and that rocks exposed in the Buffalo Fork River to the east are shallow level equivalents to the deep rocks exposed in the Tetons. Based on these observations and measurements, we hypothesize that the basement rocks of the Tetons formed in an offshore, island arc setting between $2.74-2.68 \mathrm{Ga}$, and they were accreted to the Wyoming province at about $2.67 \mathrm{Ga}$. Post-tectonic intrusion of distinctive peraluminous granites in both the Teton's (Mt. Owens quartz monzonite) and elsewhere in the Wyoming province at $2.55 \mathrm{Ga}$ strengthens our interpretation of a shared history after $2.67 \mathrm{Ga}$. If this model for the basement rocks in the Teton's holds up, it will be the first case of crustal growth by lateral accretion for the Archean Wyoming province, and one of the earliest examples of plate tectonics style crustal growth documented from anywhere in the world. Plate tectonic growth has dominated the Earth's evolution from $\sim 2.5 \mathrm{Ga}$ to the present, but it is unclear whether or not analogous processes operated before $2.5 \mathrm{Ga}$.

\section{$\downarrow \quad$ SUMMARY OF FIELD WORK}

During the fieldwork we used available geologic maps from the US Geologic Survey to locate key areas for study (Love et al., 1992). We resampled the augen gneiss, and verified field relations between the major units exposed within Teton National Park. We were also fortunate to find and collect a sample of pegmatitic, partial melt that formed during metamorphism. Zircons from this sample will give us a direct age on the timing of metamorphism and deformation. Much of our fieldwork, however, focussed on exposures of 
basement east of the Park. We spent two days in the Gros Ventre Range, two days in the Buffalo Fork River gorge, and a week north of Dubois in eroded foothills of the Absaroka Range. The rocks exposed in the Buffalo Fork gorge were particularly enlightening, as they included ultramafic rocks, Fe formation containing the Fe-amphibole grunerite, and pelitic to dacitic supracrustal rocks. This assemblage is typical of an ocean floor that has been subsequently metamorphosed, and we interpret these rocks to be remnants of the ocean basin that existed between the basement rocks of the Tetons and the rest of the Wyoming province. The basement rocks farther east, exposed near Dubois, do not appear to be related to the basement in the Tetons, lending further evidence to our exotic block model for the Tetons.

\section{$\downarrow \quad$ ANAlytical RESUlts}

\section{Nd-Sr isotopes:}

The rocks from the Tetons show a range of $\mathrm{Nd}$ isotope values, with $\mathrm{Nd}$ ranging from +3 (which is nearly a mantle value at this time) to more than -7 , which would be more typical of crustal rocks (Fig. 1). This variation is best seen in the range in Nd model ages, a measure of the time at which the REEs in the rock were extracted from a mantle reservoir. The youngest rock, the Mt. Owen granite has a low $\square$ Nd and $\mathrm{Nd}$ model age of $3.6 \mathrm{Ga}$, indicating that its source area contained significant amounts of old crust. The granite is peraluminous and both the old $\mathrm{Nd}$ model age and the rock composition are consistent with a source that included metasediments derived from the Archean crust of the Wyoming Province.

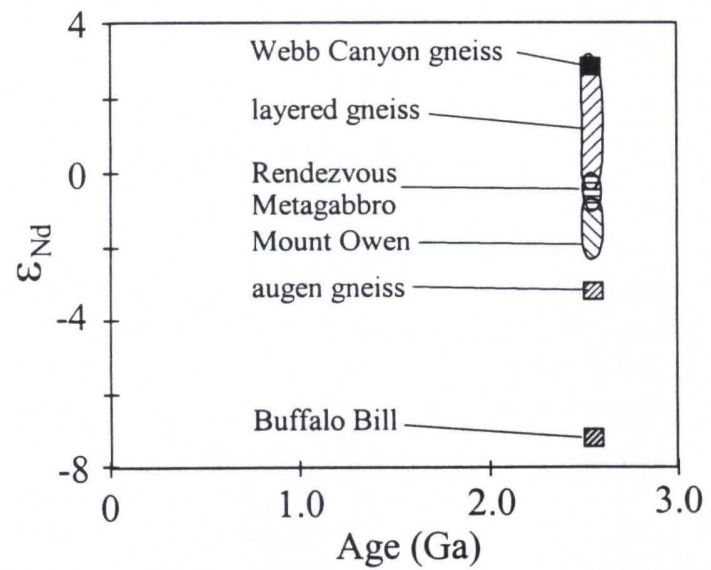

Figure 1: Variation of $\square_{\mathrm{Nd}}$ for rocks from the Tetons at 2.54 $\mathrm{Ga}$, the age of the Mt. Owen granodiorite.
Many of the samples of the layered gneiss have high $\mathrm{Nd}$ and relatively young $\mathrm{Nd}$ model ages, around $2.7 \mathrm{Ga}$. These rocks cannot be much younger than $2.68 \mathrm{Ga}$, because they are intruded by the ca. $2.68 \mathrm{Ga}$ Webb Canyon gneiss. This suggests that some of the rocks in the Tetons are of juvenile origin, in distinct contrast to gneisses in the Wind Rivers. Such "juvenile" rocks could represent island arcs or accretionary sediments.

\section{GEOCHRONOLOGY}

We have preliminary $\mathrm{U}-\mathrm{Pb}$ dates from three of the dominant rock types exposed in the Park. The distinctive, alkali feldspar megacrystic, augen gneiss (WAG of Love et al., 1992) yielded zircon with a range of ages that we interpret to indicate involvement of older crust, at least as old as $2.79 \mathrm{Ga}$, in an igneous rock that crystallized at about $2.74 \mathrm{Ga}$. This augen gneiss is either interlayered with or intrudes the complex layered gneiss that is the most widespread basement rock in the Park. Based on the $\mathrm{U}-\mathrm{Pb}$ data from the augen gneiss, we interpret the age of the layered gneiss to $b e \geq 2.74 \mathrm{Ga}$. Zircon from the Webb Canyon gneiss, a unit that intrudes both the layered and augen gneisses, are interpreted to indicate an age of $2.68 \mathrm{Ga}$ or younger. The zircon systematics of the Webb canyon and augen gneisses are complex and will require additional work to determine their ages accurately. The Rendezvous metagabbro, (Fig 2 ) on the other hand, yielded magmatic zircon with relatively simple $\mathrm{U}-\mathrm{Pb}$ systematics and analyses resulted in an age of crystallization of $2692 \pm 8 \mathrm{Ma}$ (or $2.69 \mathrm{Ga}$ ).

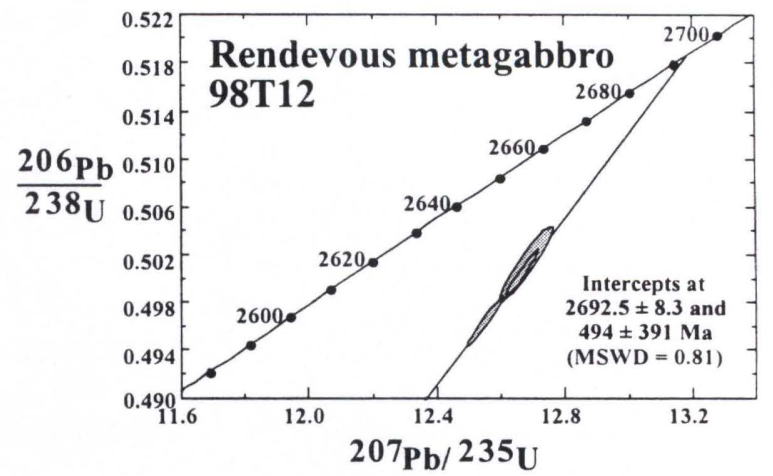




\section{SIGNIFICANCE}

Our initial work on the Tetons has shown the that the age of the last penetrative deformation in the Archean rocks of the Tetons is synchronous with the intrusion of the Webb Canyon gneiss, which has been interpreted to be younger than $2.7 \mathrm{Ga}$ (Zartman and Reed, 1998). This age is considerably younger than the last penetrative deformation in the Bighorn Mountains but is similar to the age of the last penetrative deformation in the Wind River Range (Frost et al., 1998), the Seminoe and Ferris Mountains (Bowers and Chamberlain, 1993), and the northern Laramie Range. This suggests that in the time period of ca. $2.6-2.7 \mathrm{Ga}$ an active orogenic belt extended across the southern margin of the Wyoming province. Although the basement in the Tetons appears to share a similar deformation age to those in the Wind Rivers, the isotopic compositions of the gneisses from the Tetons are distinctly different from those in the Wind River Range. The Tetons contain rocks that have had a much shorter crustal history than similar-looking gneisses in the Wind Rivers. It is possible that layered gneisses with the young $\mathrm{Nd}$ model ages in the Tetons are part of an accreted terrane. If so, this is the first evidence that exotic terranes were accreted to the margin of the Wyoming Craton in the Archean. Results from our work so far have been reported in the 1999 Joint Conference on Geology and Mineralization of Wyoming and surrounding regions (Cornia 1999) and are in the process of being written up in Mary Cornia's MS thesis.

\section{Future Plans:}

The results from our Teton studies have already had a major impact on our understanding of the evolution of the Wyoming province. It has allowed us to put together a model suggesting that the southern portion of the Wyoming province was an active orogenic margin during the period of 2.6 to 2.8 billion years ago. Much of this orogenic belt was developed on the old margin of the Wyoming province, but it is possible that some of the Tetons represent an accreted terrane. We were awarded a three year grant from NSF in Feb. 2000 to continue our study of the Wyoming Province to test this model. This grant seeks to study the Precambrian outcrops in the Tetons, Wind River Range, Seminoe-Ferris Mountains, and northern Laramie Range to see if we can constrain the age of this orogenic belt. We plan significant further work in the Tetons to see if we can map the limits of the possible accreted terrane.

\section{LITERATURE CITED}

Bowers, N.E., and Chamberlain, K.R. 1993. New structural and geochronological constraints on an Archean shear zone in the central Wyoming Province, Ferris Mountains, Carbon County, Wyoming: GSA Abstracts with Programs, v. 25, p. A47.

Cornia, M. 1999. Precambrian geology, geochemistry, and geochronology of the Teton Range, Wyoming: Programs and Abstracts for the 1999 Joint Conference on Geology and Mineralization of Wyoming and surrounding regions, Wyoming State Geological Survey, Dept. of Geology and Geophysics, Univ. of Wyoming, and Wyoming Geological Association, p. 7-8.

Frost, C.D., Frost, B.R., Chamberlain, K.R., and Hulsebosch, T.P. 1998. The Late Archean history of the Wyoming Province as recorded by granitic magmatism in the Wind River Range, Wyoming: Precambrian Research, v. 89, p. 145-173.

Hildebrandt, P.K. 1989. Petrology, thermobarometry and geochemistry of the Archean layered gneiss, Teton Range, Wyoming. unpub Master's thesis, Colorado State University. Fort Collins, CO, United States.

Love, J.D., Reed, J.C., and Christiansen, A.C. 1992. Geologic map of Grand Teton National Park, Teton County, Wyoming: U.S. Geological Survey Misc. Investigation Series, Map I-2031

Zartman, R.E. and Reed, J.C. 1998. Zircon geochronology of the Webb Canyon Gneiss and the Mount Owen quartz monzonite, Teton Range, Wyoming: Significance to dating Late Archean Metamorphism in the Wyoming Craton: The Mountain Geologist, v. 35 , no. 2 , p. $71-77$. 